\title{
Mucoepidermoid carcinoma of oral mucosa
}

\author{
Rohit Jain, ${ }^{1}$ Ranjana Mohan, ${ }^{1}$ Amarnath Janardhan, ${ }^{1}$ Rahul Jain ${ }^{2}$
}

${ }^{1}$ Department of

Periodontology, Teerthanker Mahaveer Dental College and Research Centre, Moradabad, Uttar Pradesh, India

${ }^{2}$ Guru Teg Bahadur Hospital, New Delhi, India

\section{Correspondence to} Professor Ranjana Mohan, ranjanamohan16@gmail.com

Accepted 14 March 2015

\section{DESCRIPTION}

A mucoepidermoid carcinoma is a tumour that usually occurs in the salivary glands. These tumours account for $5 \%$ of all salivary gland tumours commonly arise within the parotid gland and are the most common malignant tumour to arise in children and adults under 20 years of age. The tumour is a firm to hard mass and is usually asymptomatic. ${ }^{1}$ It can mimic most other tumours of the glands, and therefore is often considered in the differential. ${ }^{2}$ Within the oral cavity, mucoepidermoid carcinoma often resembles a mucocele. It has a female predilection and is uncommon in the first decade of life. ${ }^{3}$ We report a case with rare clinical findings. An

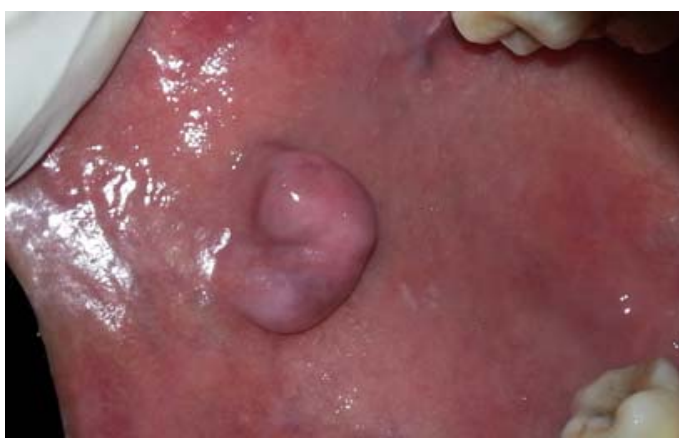

Figure 1 Swelling on the right buccal mucosa near the lip commissure.

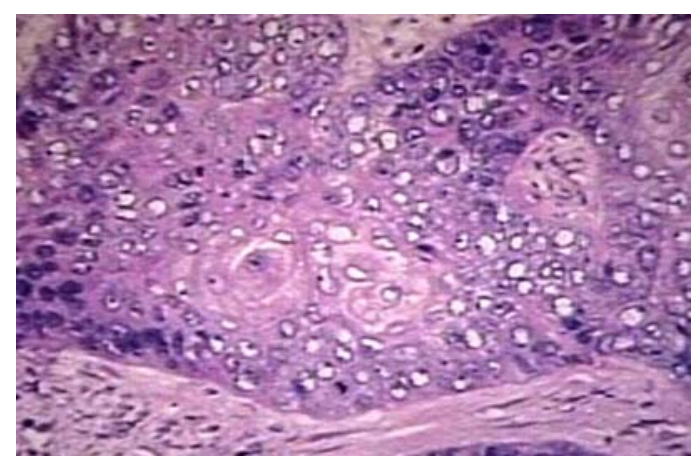

Figure 2 Histopathological examination showing nucleoli and deep eosinophilic cytoplasm arranged into groups and sheets. 18-year-old boy presented to our outpatient Department of Periodontology, Teerthanker Mahaveer Dental College and Research Centre, with a 5-month history of painless swelling on the right buccal mucosa near the lip commissure (figure 1). On examination, the swelling was well defined, smooth and oval shaped, measuring $2 \times 2 \mathrm{~cm}$. It was fluctuant, firm and non-tender on palpation. A provisional diagnosis of mucocele was established. An excisional biopsy was performed. Histopathological slides showed round-to-ovoid shaped tumour cells having vesicular nuclei with prominent nucleoli and deep eosinophilic cytoplasm arranged into groups and sheets (figure 2). The overall features indicated low-grade mucoepidermoid carcinoma of minor salivary gland.

\section{Learning points}

- Although mucoepidermoid carcinoma is seen mostly in children, it also occurs at different age groups.

- The tumour usually forms as a painless, fixed, slowly growing swelling of widely varying duration that sometimes goes through a phase of accelerated growth immediately before clinical presentation.

- Histopathological examination of such oral mucous lesions should be performed for their diagnosis.

Competing interests None.

Patient consent Obtained.

Provenance and peer review Not commissioned; externally peer reviewed.

\section{REFERENCES}

1 Som PM, Curtin HD. Head and neck imaging, Volume 1 und. Mosby. ISBN:0323009425.

2 Gustafsson H, Dahlqvist A, Carlsoo B. Mucoepidermoid carcinoma in a minor salivary gland in childhood. I Laryngol Otol 1987;101:1320-3.

3 Suquo ME, Nwagbara VI, Umana AN, et al. Giant MEC in parotid gland: a case report and review of literature. I Clin Exp Oncol 2013;2:1. 


\section{Images in...}

Copyright 2015 BMJ Publishing Group. All rights reserved. For permission to reuse any of this content visit http://group.bmj.com/group/rights-licensing/permissions.

BMJ Case Report Fellows may re-use this article for personal use and teaching without any further permission.

Become a Fellow of BMJ Case Reports today and you can:

- Submit as many cases as you like

- Enjoy fast sympathetic peer review and rapid publication of accepted articles

- Access all the published articles

- Re-use any of the published material for personal use and teaching without further permission

For information on Institutional Fellowships contact consortiasales@bmjgroup.com

Visit casereports.bmj.com for more articles like this and to become a Fellow 